\title{
Effects of dietary electrolyte balance and calcium supply on mineral and acid-base status of piglets fed a diversified diet
}

\author{
M. Bournazel ${ }^{1,2}$, M. J. Duclos ${ }^{1}$, F. Lecompte ${ }^{3}$, D. Guillou ${ }^{2}$, C. Peyronnet ${ }^{4}$, A. Quinsac ${ }^{5}$, \\ N. Même ${ }^{1}$ and A. Narcy ${ }^{1}$ * \\ ${ }^{1}$ INRAE, Université de Tours, UMR BOA, 37380 Nourilly, France \\ ${ }^{2}$ MiXscience, Campus du Groupe Avril, 2/4 avenue de Ker Lann, 35172 Bruz, France \\ ${ }^{3}$ Plateforme CIRE, Service imagerie, UMR 0085 PRC, INRA centre val de Loire, 37380 Nouzilly, France \\ ${ }^{4}$ Terres Univia, 11 rue Monceau, 75008 Paris, France \\ ${ }^{5}$ Terres Inovia, 11 rue Monge, Parc industriel, 33600 Pessac, France
}

(Received 19 November 2019 - Accepted 23 April 2020)

Journal of Nutritional Science (2020), vol. 9, e18, page 1 of 9

doi:10.1017/jns.2020.10

Abstract

Dietary electrolyte balance (dEB) is known to affect acid-base status and mineral metabolism, but is rarely considered in diet formulation for pigs. Yet, the use of a wide variety of local feedstuffs in Europe contributes to lowering the dEB and increasing the fibre content. Hence, mineral requirements may be modified and skeletal health affected. Therefore, the effects of a lower dEB and a higher dietary Ca level on acid-base balance and mineral status were assessed in young pigs fed a diversified diet. A total of twenty-four weaned pigs were fed a control moderate-dEB diet (C) or a diversified moderate-dEB (D), low-dEB (D-A) or low-dEB supplemented with Ca (D-CA) diet. Growth performance, venous blood gas and chemistry, urine $\mathrm{pH}$, mineral balance and femur characteristics were determined. With an equivalent $\mathrm{dEB}$ compared with the $\mathrm{C}$ diet, the $\mathrm{D}$ diet caused an acidification of the urine and increased the excretion of $\mathrm{P}$ as a result of a higher dietary content of $\mathrm{S}$. Low-grade metabolic acidosis occurred in piglets fed the $\mathrm{D}-\mathrm{A}$ diet with changes at systemic and urine levels. A higher excretion of ammonia and $\mathrm{P}$ in urine was observed and some bone characteristics tended to be negatively affected. Ca supplementation partially counteracted the effects of low-grade acidosis. Urine excretion of P and ammonia was alleviated and bone characteristics improved. In conclusion, a higher $\mathrm{Ca}$ supply must be considered in more diversified diets to counteract the risk of evolving towards low-grade metabolic acidosis which can negatively affect bone.

Keywords: Dietary electrolyte balance: Calcium: Acid-base balance: Bone

The maintenance of acid-base balance is crucial to ensure normal metabolic and enzymic processes. To maintain homeostasis, the ingestion/production of $\mathrm{H}^{+}$must be balanced through an effective removal of these ions from the body ${ }^{(1)}$. In this regard, buffer systems are activated to cope with changes in blood $\mathrm{pH}$ and avoid acidaemia ${ }^{(2)}$. However, a prolonged dietary acid load can result in a state of low-grade metabolic acidosis characterised by minor changes in blood $\mathrm{pH}$, within the range considered normal, but associated with several metabolic disturbances ${ }^{(3)}$. Among them, reduced $\mathrm{Ca}$ balance and increased bone resorption have been previously observed ${ }^{(4,5)}$. The skeleton is a reservoir of labile bases and cations which can be mobilised for the maintenance of blood $\mathrm{pH}$ and excretion of acid loads ${ }^{(6)}$.

\footnotetext{
Abbreviations: ADG, average daily gain; AR, apparent retention; ATTD, apparent total tract digestibility; C, control low-fibre diet; D, diet enriched in local feedstuffs with a normal dietary electrolyte balance; D-A, diet enriched in local feedstuffs with a low dietary electrolyte balance; D-CA, D-A diet supplemented with Ca; DDGS, distillers' dried grains with solubles; dEB, dietary electrolyte balance; FCR, feed conversion ratio; HU, Hounsfield units.
}

* Corresponding author: A. Narcy, email agnes.narcy@inra.fr 
Consequently, acid-base disturbances may induce adverse effects on bone strength in the long run from an early stage onward $^{(7)}$.

In pig nutrition, dietary electrolyte balance (dEB) is not widely used when formulating feed even though the maintenance of this parameter in pigs is crucial for $\operatorname{growth}^{(8,9)}$. Although the AEB is generally quite far from the threshold below which growth is reduced, it can lead to an overload of acid that needs to be eliminated from the body, thereby inducing mineral metabolism disorders ${ }^{(10)}$. In Europe, the trend to reduce the use of soyabean meal in favour of local raw materials as well as the use of free amino acids supports the need to take the dEB into account. Soyabean meal is characterised by high $\mathrm{K}$ content, a decrease of its use resulting in a significant reduction of the dEB of the diet ${ }^{(11)}$. These ingredients are also particularly rich in fibre which may interfere with the $\mathrm{dEB}^{(12)}$. In conjunction, the current trend in reducing the Ca content in pig diets (e.g. to optimise P digestibility and phytase efficiency) may intensify the deleterious effect of acidosis on the skeleton. According to Létourneau-Montminy et al. ${ }^{(13)}$, reducing the dietary $\mathrm{Ca}$ level in $\mathrm{P}$-adequate diets improves $\mathrm{P}$ digestibility and growth performance, but negatively affects the overall retention of $\mathrm{P}$ due to the specific requirement of both minerals, i.e. Ca and $\mathrm{P}$, for the development of bone tissue. In this condition of reduced Ca supply, the risk of evolving towards low-grade metabolic acidosis thus raises questions about the maintenance of skeletal integrity in pigs $^{(14)}$. Therefore, the present experiment was designed to study the effects of a lower $\mathrm{dEB}$ and a higher dietary Ca level on the acid-base balance and mineral status of young pigs fed a diversified diet, i.e. containing various local feedstuffs.

\section{Materials and methods}

The experimental protocol was approved by the Regional Ethics Committee on animal experimentation (Rennes, France) and was conducted under the guidelines of the French Ministry for Animal Research (Paris, France; authorisation no. 02402.03).

\section{Experimental diets}

All treatments were iso-energetic, iso-proteineous and equivalent in digestible amino acids. They contained maize and soyabean meal and equivalent amounts of barley $(26 \%)$ and wheat (17.7\%; Table 1). The control diet (C) corresponded to a standard weaner diet without antibiotics, formulated to meet the requirements of 10 to $25 \mathrm{~kg}$ pigs. The second diet (D) was enriched in local feedstuffs and contained $8.0 \%$ wheat bran, $6.0 \%$ sugar beet pulp and $5.0 \%$ wheat distillers' dried grains with solubles (DDGS) at the expense of maize and soyabean meal. The dEB was maintained at $148 \mathrm{mEq} / \mathrm{kg}$ like $\mathrm{C}$ using $4.8 \%$ potassium citrate. The third diet (D-A) was formulated in the same way as $\mathrm{D}$, but contained $3.35 \%$ potassium chloride $(\mathrm{KCl})$ and $9.40 \%$ calcium chloride dihydrate $\left(\mathrm{CaCl}_{2} \cdot 2 \mathrm{H}_{2} \mathrm{O}\right)$ in order to decrease the dEB to $-24 \mathrm{mEq} / \mathrm{kg}$. The fourth diet (D-CA) was similar to D-A, but $4.83 \%$ calcium carbonate $\left(\mathrm{CaCO}_{3}\right)$ was added to increase
Table 1. Composition of experimental diets (as-fed basis)

\begin{tabular}{|c|c|c|c|c|}
\hline & C & D & D-A & D-CA \\
\hline \multicolumn{5}{|l|}{ Ingredients $(\mathrm{g} / \mathrm{kg})^{\star}$} \\
\hline Maize & 303 & 175 & 173 & 168 \\
\hline Soyabean meal & 217 & $76 \cdot 5$ & $76 \cdot 5$ & $76 \cdot 7$ \\
\hline Barley & 260 & 260 & 260 & 260 \\
\hline Wheat & 177 & 177 & 177 & 177 \\
\hline Wheat bran & - & $80 \cdot 0$ & $80 \cdot 0$ & $80 \cdot 0$ \\
\hline Sugar beet pulp & - & $60 \cdot 0$ & $60 \cdot 0$ & $60 \cdot 0$ \\
\hline Wheat DDGS & - & $50 \cdot 0$ & $50 \cdot 0$ & $50 \cdot 0$ \\
\hline Casein $\mathrm{HCl}$ & $7 \cdot 80$ & 54.5 & $54 \cdot 2$ & $54 \cdot 2$ \\
\hline Soya oil & - & $27 \cdot 0$ & $28 \cdot 0$ & $28 \cdot 0$ \\
\hline $\begin{array}{l}\text { Calcium chloride } \\
\left(2 \mathrm{H}_{2} \mathrm{O}\right)\end{array}$ & - & - & 9.40 & $9 \cdot 40$ \\
\hline $\begin{array}{l}\text { Monocalcium } \\
\text { phosphate }\end{array}$ & $10 \cdot 2$ & $11 \cdot 2$ & $11 \cdot 2$ & $11 \cdot 2$ \\
\hline Calcium carbonate & 8.95 & $6 \cdot 60$ & - & 4.83 \\
\hline Potassium citrate & & 4.80 & - & - \\
\hline Salt & 3.75 & 3.38 & 3.38 & 3.38 \\
\hline Potassium chloride & - & - & 3.35 & 3.35 \\
\hline L-Lysine $\mathrm{HCl}$ & 4.60 & 4.38 & 4.38 & 4.38 \\
\hline L-Threonine & 1.65 & $2 \cdot 14$ & $2 \cdot 13$ & $2 \cdot 13$ \\
\hline DL-Methionine & 1.56 & 1.88 & 1.88 & $1 \cdot 88$ \\
\hline L-Tryptophan & 0.45 & 0.62 & 0.62 & 0.62 \\
\hline \multicolumn{5}{|c|}{ Chemical characteristics $(\mathrm{g} / \mathrm{kg}) \dagger$} \\
\hline DM & 891 & 898 & 896 & 894 \\
\hline NE (MJ/kg) & $9 \cdot 66$ & $9 \cdot 68$ & $9 \cdot 67$ & $9 \cdot 62$ \\
\hline Crude protein & 174 & 174 & 173 & 173 \\
\hline Lipids & $26 \cdot 0$ & $46 \cdot 1$ & $51 \cdot 1$ & $51 \cdot 6$ \\
\hline TDF & (110) & (137) & (176) & (165) \\
\hline Insoluble fibre & (94.6) & (121) & (111) & (140) \\
\hline Soluble fibre & (16) & $(16)$ & (65) & (25) \\
\hline Digestible P & 3.0 & 3.0 & 3.0 & 3.0 \\
\hline Total P & 5.7 & 5.6 & 6.5 & $6 \cdot 2$ \\
\hline $\mathrm{Ca}$ & $7 \cdot 7(6.9)$ & $7 \cdot 6(6 \cdot 5)$ & $7.7(6.4)$ & $9.5(8.2)$ \\
\hline Ca:dP & $2 \cdot 6$ & 2.5 & $2 \cdot 6$ & $3 \cdot 2$ \\
\hline $\mathrm{K}$ & $7.5(7 \cdot 2)$ & $7.5(7 \cdot 3)$ & $7.5(7.9)$ & $7.5(7 \cdot 8)$ \\
\hline $\mathrm{Na}$ & $1.6(1.5)$ & $1 \cdot 6(1 \cdot 2)$ & $1 \cdot 6(1 \cdot 2)$ & $1.6(1.4)$ \\
\hline $\mathrm{Cl}$ & $4 \cdot 0(5 \cdot 1)$ & $4.0(4 \cdot 9)$ & $10(11)$ & $10(12)$ \\
\hline $\mathrm{dEB}(\mathrm{mEq} / \mathrm{kg})$ & $148(104)$ & $148(99)$ & $-24(-60)$ & $-24(-82)$ \\
\hline $\mathrm{S}$ & $1.9(2.0)$ & $1.9(2.3)$ & $1.9(2.4)$ & $1.9(2.3)$ \\
\hline
\end{tabular}

$C$, control low-fibre diet; D, diet enriched in local feedstuffs with a normal dietary electrolyte balance; D-A, diet enriched in local feedstuffs with a low dietary electrolyte balance; D-CA, D-A diet supplemented with Ca; DDGS, distillers' dried grains with solubles; NE, net energy; TDF, total dietary fibre; $\mathrm{dEB}$, dietary electrolyte balance. ${ }^{*}$ Premix $(0.50 \%)$ was added in all diets: $10000 \mathrm{IU}(3000 \mu \mathrm{g})$ vitamin A (retinol); 2000 IU $(50 \mu \mathrm{g})$ vitamin $\mathrm{D}_{3}$ (cholecalciferol); $20 \mathrm{mg}$ vitamin $\mathrm{E}$ (tocopherol); $2 \mathrm{mg}$ vitamin $\mathrm{K}_{3}$ (menadione); $2 \mathrm{mg}$ vitamin $\mathrm{B}_{1}$ (thiamine); $5 \mathrm{mg}$ vitamin $\mathrm{B}_{2}$ (riboflavin); $20 \mathrm{mg}$ vitamin $\mathrm{B}_{3}$ (vitamin $\mathrm{PP}$, niacin); $11 \mathrm{mg}$ vitamin $\mathrm{B}_{5}$ (calcium pantothenate); $5 \mathrm{mg}$ vitamin $\mathrm{B}_{6}$ (pyridoxine); $0.2 \mathrm{mg}$ vitamin $\mathrm{B}_{8}$ (biotin, vitamin $\mathrm{H}$ ); $1 \mathrm{mg}$ vitamin $\mathrm{B}_{9}$ (folic acid); $0.03 \mathrm{mg}$ vitamin $\mathrm{B}_{12}$ (cyanocobalamin); $600 \mathrm{mg}$ choline chloride; $104 \mathrm{mg} \mathrm{Fe}$ $\left(\mathrm{FeCO}_{3}\right) ; 20 \mathrm{mg} \mathrm{Cu}\left(\mathrm{CuSO}_{4}\right) ; 40 \mathrm{mg} \mathrm{Mn} \mathrm{(MnO);} 99 \mathrm{mg} \mathrm{Zn} \mathrm{(ZnO);} 1 \mathrm{mg}$ Co $\left(\mathrm{CoCO}_{3}\right) ; 0.6 \mathrm{mg}$ iodine $\left(\mathrm{Ca}\left(\mathrm{IO}_{3}\right)_{2}\right) ; 0.3 \mathrm{mg} \mathrm{Se}\left(\mathrm{Na}_{2} \mathrm{SeO}_{3}\right) ; 2.95 \mathrm{~g} \mathrm{Ca}\left(\mathrm{CaCO}_{3}\right)$. $\dagger$ Analysed values in parentheses.

the level of $\mathrm{Ca}$, without modifying the dEB. Digestible $\mathrm{P}$ was equivalent across treatments and the $\mathrm{Ca}$ level was adjusted to obtain a Ca:digestible $\mathrm{P}$ ratio of $2 \cdot 6$ in all diets ${ }^{(15)}$, except for the D-CA diet in which it was increased to $3 \cdot 2$.

\section{Animals and experimental procedures}

The experiment included twenty-four castrated male Piétrain $x$ (Landrace $\times$ Large White) piglets weighing $9 \cdot 6 \pm 0.5 \mathrm{~kg}$ at $28 \mathrm{~d}$ old (day 0 of the experiment). The animals were regularly monitored by qualified and authorised staff in order to immediately intervene in case of a problem. They were housed individually in cages $(0.6 \times 0.8 \mathrm{~m})$ equipped with a grid and a slurry pit 
under a slatted floor for faeces and urine collection. They were fed ad libitum and had free access to water. The ambient temperature of the housing was maintained at $28^{\circ} \mathrm{C}$ and decreased to reach $24^{\circ} \mathrm{C}$ at the end of the experiment. At day 8 , blocks of four pigs were created, each from the same litter and with a similar body weight, resulting in six blocks of male piglets. Piglets within a block were allocated to one of the four dietary treatments (six piglets per diet). The piglets were offered an equal quantity of feed daily that was distributed in two equivalent meals corresponding to $4 \%$ of their body weight. Daily feed intake was recorded individually during the experimental period. The collection period started on day 14 and ended on day 22 after an overnight fast to ensure that the intestine was empty. Faeces were collected at meal times (twice per d) and pooled per pig. Finally, faeces were mixed thoroughly with water, sampled and weighed. The urine was acidified by adding $3 \mathrm{ml}$ of $10 \%$ sulfuric acid/l of urine to maintain a $\mathrm{pH}<2$ (to prevent microbiota development) and was also collected individually and stored at $-20^{\circ} \mathrm{C}$. At day 25 , four pigs per diet were fitted surgically with a catheter. After an overnight fast, the catheter was inserted into the jugular vein after injection of an appropriate anaesthetic for piglets (premedication with Imalgène 1000 (Merial); $1 \mathrm{ml}$ per $10 \mathrm{~kg}$ of body weight by the intramuscular route, 5 to $10 \mathrm{~min}$ before surgery) under general anaesthesia (administrated by inhalation with a face mask of isoflurane; Elvetis) in a surgery room. The catheter tube was inserted under the skin, externalised at the dorsum of the neck, and connected to a bag taped to the skin. The piglets were then returned to their cages to wake up and rest. The catheters were flushed every $2 \mathrm{~d}$ with $5 \mathrm{ml}$ of sterile saline solution containing $1 \%$ heparin. After $10 \mathrm{~d}$ of adaptation (day 35) to the catheter and to handling by humans, blood samples were taken during 8 h. Blood parameters $\left(\mathrm{pH}, \mathrm{pCO}_{2}, \mathrm{HCO}_{3}^{-}\right.$, anion gap, $\mathrm{Na}^{+}, \mathrm{K}^{+}$, $\mathrm{Cl}^{-}$) were immediately measured using a blood gas analyser (ABL80 Flex Basic; Radiometer S.A.S.). Simultaneously, urine was collected to measure the $\mathrm{pH}$ and ammonia excretion. The piglets were weighed at day 0 , day 8 and day 36 . At the end of the experiment, individual pigs received half of their daily feed allowance in the morning and the other half $2.5 \mathrm{~h}$ before slaughter. The piglets were stunned electrically and killed by exsanguination at the end of the experiment. The femurs were collected and stored at $-20^{\circ} \mathrm{C}$ for further analyses.

\section{Analyses}

All samples were analysed in duplicate. DM of the diets was determined after drying at $103^{\circ} \mathrm{C}$ for $4 \mathrm{~h}$. Insoluble, soluble and total dietary fibre was quantified according to the method of Prosky et al. ${ }^{(16)}$. One sample of faeces per pig was analysed for DM content and one sample was freeze-dried. Freeze-dried faecal samples were ground through a $1 \mathrm{~mm}$ grid. Samples were then ashed at $550^{\circ} \mathrm{C}$ for $8 \mathrm{~h}$ in a muffle furnace and solubilised with $16 \mathrm{M}$-nitric acid and $30 \%$ hydrogen peroxide on a digestion block to dryness and finally diluted in $0.4 \mathrm{M}$-nitric acid. Total $\mathrm{P}, \mathrm{Ca}, \mathrm{K}, \mathrm{Na}, \mathrm{S}$ and $\mathrm{Cl}$ were measured in the diets, faeces and urine to determine the apparent total tract digestibility (ATTD) and apparent retention (AR) and in the femurs to determine mineral contents. Total $\mathrm{P}, \mathrm{Ca}, \mathrm{Mg}, \mathrm{K}, \mathrm{Na}$ and $\mathrm{S}$ were analysed using an inductive coupled plasma atomic emission spectrometer (ICP OES Thermoscientific ${ }^{\mathrm{TM}}$ iCAP $^{\mathrm{TM}}$ 7200; method 990.08; AOAC International, 2006). Chloride was analysed using a kit (kit Chlorures; Biolabo). The right femurs were broken and then defatted using diethyl ether, dried at $103^{\circ} \mathrm{C}$ for $18 \mathrm{~h}$, and finally ashed in a muffle furnace at $600^{\circ} \mathrm{C}$ for $16 \mathrm{~h}$. The left femurs were scanned using a clinical computed tomography machine (Somatom Définition AS128; Siemens) with scan parameters set at $140 \mathrm{kV}$ tube voltage and $500 \mathrm{mAs}$ current. The image acquisition mode was $32 \mathrm{~cm} \times 512$ pixels matrix size with a slice thickness of $0.4 \mathrm{~mm}$ and a resolution of $625 \mu \mathrm{m}$. The images were converted into Digital Imaging and Communication in Medicine (DICOM) format for analysis using the SINGO.VIA software. Bone mineral density was estimated and given in Hounsfield units $(\mathrm{HU})$ by the scanner software and later converted into $\mathrm{g} / \mathrm{cm}^{3}$ using a phantom (Electron Density Phantom Model 062M). Total bone was defined in intervals from 200 to $3000 \mathrm{HU}$ according to Militist et al. ${ }^{(17)}$. Trabecular and cortical bones were defined in intervals from 200 to $800 \mathrm{HU}$, and 801 to $3000 \mathrm{HU}$, respectively, according to Sherlock et al. ${ }^{(18)}$.

\section{Calculations and statistical analysis}

ATTD was calculated as follows (DM basis):

ATTD $(\%)=\left(\left(X_{\text {intake }}(\mathrm{g} / \mathrm{d})-X_{\text {excreted in faces }}(\mathrm{g} / \mathrm{d})\right) /\right.$ $\left.\left(X_{\text {intake }}(\mathrm{g} / \mathrm{d})\right)\right) \times 100$.

AR was calculated as follows:

AR $(\%)=\left(\left(X_{\text {intake }}(\mathrm{g} / \mathrm{d})-X_{\text {excreted in faeces }}(\mathrm{g} / \mathrm{d})-X_{\text {excreted }}\right.\right.$ in urine $(\mathrm{g} / \mathrm{d}) /\left(X_{\text {intake }}(\mathrm{g} / \mathrm{d})\right) \times 100$.

Urinary elimination was calculated as follows:

Urinary elimination $(\%)=\left(X_{\text {excreted in urine }}(\mathrm{g} / \mathrm{d}) / X_{\text {absorbed }}\right.$ $(\mathrm{g} / \mathrm{d})) \times 100$,

with $X$ being the mineral considered.

The widths of the diaphysis and medullary cavity were measured at the middle of the diaphysis, and the cortical thickness and area were calculated as:

Cortical thickness $(\mathrm{cm})=$ diaphysis width $(\mathrm{cm})-$ medullary cavity width $(\mathrm{cm})$.

Cortical area $\left(\mathrm{cm}^{2}\right)=\pi \times\left(\right.$ diaphysis width $(\mathrm{cm})^{2}-$ medullary cavity $\left.(\mathrm{cm})^{2}\right)$.

Determination of the sample size was based on a power calculation using the estimated mean and standard deviation for the ATTD of P (26.2 (SD 5.5)\%) and blood pH (7.4963 (SD $0 \cdot 017)$ ) observed in previous studies ${ }^{(19,20)}$. Consequently, we estimated that in order to detect a change in the ATTD of $\mathrm{P}$ of approximately nine points, at a significance level of 0.05 , with a power of $80 \%$ in a two-sided $t$ test, six animals per group should be used for the digestive trial. For blood analyses, four animals per group are necessary to detect a change of blood $\mathrm{pH}$ of 0.03 units.

All data were analysed using the MIXED procedure from SAS (SAS Institute Inc.) as appropriate for a randomised complete block design after the normality of the variables had been checked. The block factor represented six consecutive cages and piglets were the experimental unit. The model included diet as a fixed effect and block as a random effect. Block was considered to be a random effect. Differences were considered 
Table 2. Average weight, feed intake and feed efficiency of piglets during the experimental period*

(Mean values and pooled standard errors)

\begin{tabular}{lrrrrrr}
\hline & C & D & D-A & D-CA & SEM & $P$ \\
\hline Initial BW (kg) & $11 \cdot 2$ & 11.1 & 11.4 & 11.3 & 0.08 & 0.31 \\
Final BW (kg) & $24 \cdot 6^{\mathrm{b}}$ & $26.9^{\mathrm{a}}$ & $25.4^{\mathrm{a}}$ & $25 \cdot 9^{\mathrm{a}}$ & 0.27 & 0.023 \\
ADG (g/d) & $612^{\mathrm{b}}$ & $718^{\mathrm{a}}$ & $640^{\mathrm{b}}$ & $662^{\mathrm{a}, \mathrm{b}}$ & 12.2 & 0.008 \\
ADFI (g/d) & 786 & 825 & 804 & 799 & 8.98 & 0.41 \\
FCR & $1.31^{\mathrm{a}}$ & $1.17^{\mathrm{b}}$ & $1.29^{\mathrm{a}}$ & $1.23^{\mathrm{a}, \mathrm{b}}$ & 0.02 & 0.007
\end{tabular}

C, control low-fibre diet; D, diet enriched in local feedstuffs with a normal dietary electrolyte balance; D-A, diet enriched in local feedstuffs with a low dietary electrolyte balance; D-CA, D-A diet supplemented with $\mathrm{Ca}$; BW, body weight; ADG, average daily gain; $A D F I$, average daily feed intake; FCR, feed conversion ratio.

a,b Mean values within a row with unlike superscript letters were significantly different $(P<0.05)$.

${ }^{*} n 6$.

to be significant at $P<0 \cdot 05$ and to be a trend at $0 \cdot 05 \leq P<0 \cdot 10$. When a significant difference between means was observed, post hoc significance between treatment means was determined using the Bonferroni test. All values are presented as means and pooled standard errors of the mean.

\section{Results}

No adverse effects to the piglets' welfare occurred during the experiment, and, consequently, no medication was used. Operated animals recovered well from the surgery and blood samplings were performed without any issues. The chemical characteristics analysed in the experimental diets were in accordance with the expected values (Table 1) and crude protein was equivalent in the four diets. The inclusion of $\mathrm{CaCl}_{2}$ increased the dietary $\mathrm{Cl}$ content and decreased the $\mathrm{dEB}$ as expected. The inclusion of $\mathrm{Ca}$ increased the dietary $\mathrm{Ca}$ content and consequently the $\mathrm{Ca}: \mathrm{P}$ ratio, as expected. Diets were formulated to have the same content of $\mathrm{Na}$ and $\mathrm{K}$. The analyses, presented in Table 1, showed few variations, mostly for $\mathrm{Na}$ (from 1.2 to $1.5 \mathrm{~g} / \mathrm{kg}$ ).

\section{Growth performance}

The D, D-A and D-CA diets increased the final body weight of the piglets compared with $C(+1.5 \mathrm{~kg} ; \quad P=0.023)$. The $\mathrm{D}$ diet increased the average daily gain (ADG) $(+17 \%$; $P=0.008)$ and decreased the feed conversion ratio (FCR) $(-11 \% ; P=0 \cdot 007)$ compared with the $\mathrm{C}$ diet (Table 2). The D-A diet decreased the ADG $(-11 \% ; P=0 \cdot 008)$ and increased FCR $(+10 \% ; P=0.007)$ compared with the $\mathrm{D}$ diet. Feed intake was unchanged among treatments.

\section{Blood gas and urinary $\mathrm{pH}$}

The diets did not affect blood $\mathrm{pH}$ or $\mathrm{K}^{+}$and $\mathrm{Ca}$ concentration (Table 3). The $\mathrm{D}$ diet significantly reduced urine $\mathrm{pH}$ compared with the $\mathrm{C}$ diet $(-8 \cdot 2 \% ; P<0 \cdot 001)$. Chloride addition (D-A) further reduced the urine $\mathrm{pH}$ compared with the $\mathrm{D}$ diet $(-10 \% ; P<0.001)$. Blood $\mathrm{pCO}_{2}, \mathrm{HCO}_{3}^{-}$and base excess were significantly reduced in piglets fed the $\mathrm{D}-\mathrm{A}$ diet compared with those fed the $\mathrm{C}$ diet $(-5 \cdot 8,-4 \cdot 7$ and -22 , respectively). Blood $\mathrm{Na}^{+}$and $\mathrm{Cl}^{-}$were significantly increased in piglets fed the D-A diet compared with those fed the $\mathrm{C}$ diet $(+2 \%)$ and ammonia excretion enhanced by 5 -fold. Ca addition (D-CA) did not counteract the effect of $\mathrm{Cl}$ overload on blood and urine parameters, but tended to improve them. The D-CA diet reduced phosphataemia compared with the $\mathrm{D}$ diet and $\mathrm{pCO}_{2}$ and urinary $\mathrm{pH}$ compared with the $\mathrm{C}$ diet. Blood $\mathrm{HCO}_{3}^{-}$and base excess were lower and anion gap and $\mathrm{Cl}^{-}$higher in pigs fed the D-CA diet than in pigs fed the $\mathrm{C}$ and $\mathrm{D}$ diets. The $\mathrm{D}-\mathrm{CA}$ diet induced an increase in ammonia excretion compared with the $\mathrm{C}$ diet.

\section{Mineral balance}

The D-A diet increased P intake, followed by the D-CA and D diets (from 2.32 for $\mathrm{C}$ to $2.69 \mathrm{~g} / \mathrm{d}$ for $\mathrm{D}-\mathrm{A} ; P<0.001$ ), and increased the amount of $\mathrm{P}$ absorbed compared with the $\mathrm{C}$ diet (Table 4; 1.68 v. $1.37 \mathrm{~g} / \mathrm{d} ; P=0.001$ ). The $\mathrm{D}$ diet increased the amount of urine $\mathrm{P}$ (four-fold; $P<0 \cdot 001$ ) and its percentage of urinary elimination $(+3.48$ points; $P<$ 0.001) compared with the $\mathrm{C}$ diet. These parameters were also significantly increased in piglets fed the D-A diet compared with the $\mathrm{D}$ diet $(+75 \%, P<0.001$; and +3.42 points, $P<0 \cdot 001$, respectively). The D-CA diet decreased these two parameters compared with the D-A diet $(-79 \%, P<0 \cdot 001$; and $-6 \cdot 07$ points, $P<0 \cdot 001$, respectively).

The D-CA diet increased Ca intake, the amount absorbed and retained compared with the other diets $(+28 \%, P<$ $0.001 ;+32 \%, P<0.001$; and $+22 \%, P<0.001$, respectively). The $\mathrm{D}$ diet decreased the amount of $\mathrm{Ca}$ excreted in the urine $(-65 \% ; P<0.001)$ compared with the $\mathrm{C}$ diet. The $\mathrm{D}$ and $\mathrm{D}-\mathrm{A}$ diets decreased urinary elimination of $\mathrm{Ca}$ compared with the $\mathrm{C}$ and $\mathrm{D}-\mathrm{CA}$ diets $(-8.21$ points; $P<0 \cdot 001)$. The $\mathrm{D}-\mathrm{CA}$ diet increased the amount of $\mathrm{Ca}$ excreted in faeces compared with the D-A diet $(+30 \% ; P=0.026)$ and increased the amount excreted in the urine compared with the D and D-A diets $(+178 \% ; P<0 \cdot 001)$.

The $\mathrm{D}$ diet decreased $\mathrm{Na}$ intake compared with the $\mathrm{C}$ and D-CA diets $(-14 \% ; P<0 \cdot 001)$. The $\mathrm{D}$ and $\mathrm{D}$-A diets decreased the amount of $\mathrm{Na}$ absorbed $(-21 \% ; P<0.001)$. The addition of $\mathrm{Cl}$ in the diversified diets (D-A and D-CA) decreased the amount of $\mathrm{Na}$ excreted in the faeces $(-41 \% ; P=0 \cdot 045)$. The D-CA diet increased $\mathrm{Na}$ intake compared with the $\mathrm{D}$ and $\mathrm{D}$-A diets $(+20 \%$; $P<0.001)$ and increased the ATTD of Na compared with the D diet ( +10 points; $P=0 \cdot 029)$.

The $\mathrm{D}$ diet increased $\mathrm{K}$ intake compared with the $\mathrm{C}$ diet $(+6 \% ; P<0 \cdot 001)$. The $\mathrm{D}-\mathrm{A}$ diet increased $\mathrm{K}$ excreted in faeces compared with the $\mathrm{D}$ diet $(+28 \%)$ and the $\mathrm{C} \operatorname{diet}(+44 \%$; $P=0 \cdot 001)$. The D-A diet decreased the ATTD of $\mathrm{K}$ compared with the $\mathrm{C}$ diet $(-7 \cdot 1$ points; $P=0 \cdot 042)$. D-A and D-CA increased $\mathrm{K}$ intake $(+8 \% ; P<0 \cdot 001)$, the amount excreted in the urine $(+27 \% ; P=0 \cdot 019)$ and the urinary elimination $(+16 \cdot 3$ points; $P=0 \cdot 018)$. Conversely, $\mathrm{Cl}$ addition decreased the amount of $\mathrm{K}$ retained $(-49 \% ; P=0 \cdot 025)$ and the AR of $\mathrm{K}(-12 \cdot 4$ points; $P=0 \cdot 011)$. The D-CA diet increased the amount of $\mathrm{K}$ excreted in faeces compared with the $\mathrm{C} \operatorname{diet}(+32 \% ; P=0 \cdot 001)$.

Concerning $\mathrm{S}$, the diversified diets (D, D-A and D-CA) increased intake $(+23 \% ; P<0 \cdot 001)$, the amount absorbed 
Table 3. Effect of dietary treatments on venous blood gas, serum chemistry, urine $\mathrm{pH}$ and ammonia excretion of piglets* (Mean values and pooled standard errors)

\begin{tabular}{|c|c|c|c|c|c|c|}
\hline & $\mathrm{C}$ & $\mathrm{D}$ & $D-A$ & $\mathrm{D}-\mathrm{CA}$ & SEM & $P$ \\
\hline \multicolumn{7}{|l|}{ Blood } \\
\hline $\mathrm{pH}$ & 7.466 & 7.470 & 7.463 & 7.447 & 0.002 & 0.22 \\
\hline $\mathrm{pCO}_{2}(\mathrm{mmHg})$ & $45 \cdot 12^{a}$ & $44 \cdot 81^{a, b}$ & $42 \cdot 49^{b}$ & $43 \cdot 41^{\mathrm{b}}$ & 0.23 & $<0.001$ \\
\hline $\mathrm{HCO}_{3}^{-}(\mathrm{mmol} / \mathrm{l})$ & $30 \cdot 88^{a}$ & $30 \cdot 46^{a, b}$ & $29 \cdot 43^{\mathrm{b}, \mathrm{c}}$ & $28 \cdot 68^{c}$ & $0 \cdot 18$ & $<0.001$ \\
\hline Anion gap (mmol/l) & $15 \cdot 8^{\mathrm{b}}$ & $15 \cdot 8^{\mathrm{b}}$ & $16 \cdot 2^{\mathrm{a}, \mathrm{b}}$ & $16 \cdot 6^{\mathrm{a}}$ & 0.11 & 0.007 \\
\hline $\mathrm{BE}(\mathrm{mmol} / \mathrm{l})$ & $7 \cdot 74^{\mathrm{a}}$ & $7 \cdot 17^{\mathrm{a}, \mathrm{b}}$ & $6 \cdot 03^{b, c}$ & $5 \cdot 31^{\mathrm{c}}$ & 0.19 & $<0.001$ \\
\hline $\mathrm{Na}^{+}(\mathrm{mmol} / \mathrm{l})$ & $136 \cdot 8^{\mathrm{b}}$ & $138 \cdot 8^{\mathrm{a}, \mathrm{b}}$ & $139 \cdot 4^{a}$ & $138 \cdot 0^{a, b}$ & 0.35 & 0.040 \\
\hline $\mathrm{K}^{+}(\mathrm{mmol} / \mathrm{l})$ & 4.52 & 4.52 & 4.58 & 4.41 & 0.03 & 0.13 \\
\hline $\mathrm{Cl}^{-}(\mathrm{mmol} / \mathrm{l})$ & $97 \cdot 0^{b}$ & $97 \cdot 4^{\mathrm{b}}$ & $99 \cdot 4^{a}$ & $98 \cdot 6^{a}$ & 0.18 & $<0.001$ \\
\hline $\mathrm{Ca}^{2+}(\mathrm{mg} / \mathrm{l})$ & $87 \cdot 8$ & 87.9 & $88 \cdot 1$ & $87 \cdot 1$ & 0.39 & 0.77 \\
\hline Phosphate (mg/l) & $80 \cdot 0^{a, b}$ & $82 \cdot 9^{a}$ & $79 \cdot 9^{a, b}$ & $76 \cdot 6^{b}$ & 0.76 & $<0.001$ \\
\hline \multicolumn{7}{|l|}{ Urine } \\
\hline $\mathrm{pH}$ & $7 \cdot 325^{a}$ & $6 \cdot 720^{b}$ & $6.032^{\mathrm{c}}$ & $6.459^{\mathrm{b}, \mathrm{c}}$ & 0.09 & $<0.001$ \\
\hline Ammonia (mg) & $30 \cdot 4^{\mathrm{c}}$ & $47 \cdot 8^{\mathrm{b}, \mathrm{c}}$ & $142^{\mathrm{a}}$ & $103^{a, b}$ & $10 \cdot 8$ & $<0.001$ \\
\hline
\end{tabular}

C, control low-fibre diet; D, diet enriched in local feedstuffs with a normal dietary electrolyte balance; D-A, diet enriched in local feedstuffs with a low dietary electrolyte balance; D-CA, D-A diet supplemented with Ca; BE, base excess determined by blood gas analysis.

$a, b, c$ Mean values within a row with unlike superscript letters were significantly different $(P<0.05)$

${ }^{*} n 4$; results for individual pigs reflect the average analysis of eight samples per animal.

$(+24 \%, P<0.001)$ and the amount excreted in the urine $(+43 \% ; P<0 \cdot 001)$. The amount of $\mathrm{S}$ excreted in the faeces and the amount retained tended to be increased.

The $\mathrm{D}$ diet did not affect the $\mathrm{Cl}$ balance. On the contrary, $\mathrm{D}-\mathrm{A}$ increased $\mathrm{Cl}$ intake $(+127 \% ; P<0 \cdot 001)$, the amount of $\mathrm{Cl}$ excreted in the faeces $(+69 \% ; P=0.002)$ and the amount of $\mathrm{Cl}$ absorbed $(+132 \% ; \mathrm{P}<0 \cdot 001)$ compared with the $\mathrm{C}$ and $\mathrm{D}$ diets. The $\mathrm{D}-\mathrm{A}$ diet decreased the $\mathrm{AR}$ of $\mathrm{Cl}(-19 \cdot 8$ points; $P=0 \cdot 014)$ and increased urinary elimination $(+15 \cdot 5$ points; $P=0.009)$ compared with the $\mathrm{D}$ diet. Chloride addition in the $\mathrm{D}$ diets (D-A and D-CA) increased the ATTD of Cl compared with the $\mathrm{D}$ diet $(+3 \cdot 2$ points; $P=0 \cdot 004)$, the amount of $\mathrm{Cl}$ excreted in urine $(+170 \% ; P<0.001)$ and the amount of $\mathrm{Cl}$ retained $(+56 \% ; P=0.003)$ compared with the $\mathrm{C}$ and $\mathrm{D}$ diets. The D-CA diet increased $\mathrm{Cl}$ intake $(+7 \%, P<0.001)$ and the amount of $\mathrm{Cl}$ absorbed $(+7 \% ; P<0 \cdot 001)$ compared with the D-A diet.

\section{Femur characteristics}

Chloride addition in the diversified diets (D-A and D-CA) increased the width of the medullary cavity compared with the $\mathrm{C}$ diet (Table 5; $+11 \% ; P=0 \cdot 014$ ). The D-CA diet increased the diaphyseal width compared with the $\mathrm{C}$ diet $(+13 \% ; P=0.017)$ and the cortical area compared with the $C$ and D-A diets $(+29 \% ; P=0 \cdot 020)$. The D-CA and D diets increased $\mathrm{P}$ bone deposition compared with the $\mathrm{C}$ diet $(+12 \% ; P=0 \cdot 045)$.

\section{Discussion}

With the same $\mathrm{dEB}$ as the $\mathrm{C}$ diet, the $\mathrm{D}$ diet had an acidifying effect at the urinary level. Higher total S content was observed in the $\mathrm{D}$ diet, probably due to the inclusion of DDGS. According to Kerr \& Surshon ${ }^{(21)}$, the use of sulfuric acid in the dry grind process of DDGS leads to increased total $S$ by 5-fold compared with maize. This results in higher urinary excretion, which partly explains the significant decrease in the urinary $\mathrm{pH}$. Additionally, even if fermentations in the caecum were not enhanced in the diversified diets (data not shown), the production of organic anions other than SCFA, such as succinate, lactate and galacturonate ${ }^{(22)}$, or active fermentation in the distal part of the colon cannot be excluded $^{(23)}$. The effect of these organic anions on acid-base balance is still not fully understood, but one of the hypotheses involves an anionic exchange between SCFA and $\mathrm{HCO}_{3}^{-}$, transferred from the extracellular body fluids into the colonic lumen ${ }^{(24)}$. The diets were expected to be equivalent in terms of digestible $\mathrm{P}$, but the increase in total $\mathrm{P}$ intake resulted in higher absorbed P. Despite the acidification of the urine in piglets fed the $\mathrm{D}$ diet compared with those fed the $\mathrm{C}$ diet, bone mineralisation was improved, probably due to a higher amount of absorbed P. However, the optimal level of bone mineralisation was probably not achieved due to a lack of $\mathrm{Ca}$ as suggested by the higher $\mathrm{P}$ and lower $\mathrm{Ca}$ urinary excretion, which illustrate a metabolic imbalance. Indeed, $\mathrm{P}$ and $\mathrm{Ca}$ are deposited together in the mineral matrix of bones in the form of hydroxyapatite $^{(25)}$. Bone mineralisation thus depends on the availability of both minerals at the metabolic level, the lack of one of the two minerals inducing the excretion of the other ${ }^{(26)}$. Mineral digestibility was not affected by the higher content in dietary fibre of the diversified diets, which was mostly insoluble. Conversely, Dersjant-Li et al. ${ }^{(12)}$ showed that increasing dietary NSP content increased apparent digestibility of $\mathrm{Cl}, \mathrm{Na}$ and $\mathrm{K}$ in the first part of the small intestine. Levrat-Verny et al. ${ }^{(27)}$ reported an improvement in $\mathrm{Ca}, \mathrm{Mg}$ and $\mathrm{Fe}$ absorption in rats fed whole-wheat flour compared with those fed white flour, which was probably due to the microbial breakdown of fibre. Indeed, fermentation can lower hindgut $\mathrm{pH}$ and increase SCFA production, thus favouring solubilisation and absorption of minerals ${ }^{(28-31)}$. In the present study, we observed neither a decrease in caecal or colic $\mathrm{pH}$, nor a modification of the SCFA profile (data not shown). The duration of the experiment or the gap in the fibre content between the $\mathrm{C}$ and $\mathrm{D}$ diets may have been insufficient to induce any significant effects.

Decreasing the dEB from 100 to -60 induces a deterioration of ADG and FCR without modifying feed intake. It could be thus hypothesised that the lower feed efficiency 
Table 4. Influence of dietary treatments on mineral balance of piglets* (Mean values and pooled standard errors)

\begin{tabular}{|c|c|c|c|c|c|c|}
\hline & $\mathrm{C}$ & $\mathrm{D}$ & D-A & $\mathrm{D}-\mathrm{CA}$ & SEM & $P$ \\
\hline \multicolumn{7}{|l|}{$\mathrm{P}$} \\
\hline Intake $(\mathrm{g} / \mathrm{d})$ & $2 \cdot 32^{d}$ & $2 \cdot 49^{c}$ & $2 \cdot 69^{a}$ & $2 \cdot 60^{\mathrm{b}}$ & 0.03 & $<0.001$ \\
\hline Excreted in faeces $(\mathrm{g} / \mathrm{d})$ & 0.95 & 0.94 & 1.01 & 1.06 & 0.03 & 0.14 \\
\hline Absorbed $(\mathrm{g} / \mathrm{d})$ & $1 \cdot 37^{\mathrm{c}}$ & $1.56^{a, b}$ & $1 \cdot 68^{\mathrm{a}}$ & $1.54^{a, b}$ & 0.03 & 0.001 \\
\hline ATTD $(\%)$ & $59 \cdot 2$ & 62.5 & $62 \cdot 4$ & $59 \cdot 1$ & 0.94 & 0.23 \\
\hline Urinary excreted (g/d) & $0.02^{\mathrm{c}}$ & $0.08^{b}$ & $0.14^{a}$ & $0.03^{b, c}$ & 0.01 & $<0.001$ \\
\hline Retained $(\mathrm{g} / \mathrm{d})$ & 1.36 & 1.48 & 1.53 & 1.50 & 0.03 & 0.071 \\
\hline AR $(\%)$ & 58.4 & $59 \cdot 4$ & $56 \cdot 1$ & $57 \cdot 8$ & 0.95 & 0.52 \\
\hline Urinary elimination (\%)† & $1.48^{\mathrm{C}}$ & $4.96^{\mathrm{b}}$ & $8 \cdot 38^{a}$ & $2 \cdot 34^{b, c}$ & 0.72 & $<0.001$ \\
\hline \multicolumn{7}{|l|}{$\mathrm{Ca}$} \\
\hline Intake (g/d) & $2 \cdot 78^{b}$ & $2 \cdot 70^{\mathrm{b}}$ & $2 \cdot 68^{b}$ & $3.47^{\mathrm{a}}$ & 0.07 & $<0.001$ \\
\hline Excreted in faeces $(\mathrm{g} / \mathrm{d})$ & $1 \cdot 22^{\mathrm{a}, \mathrm{b}}$ & $1 \cdot 22^{a, b}$ & $1 \cdot 15^{\mathrm{b}}$ & $1.50^{\mathrm{a}}$ & 0.05 & 0.026 \\
\hline Absorbed $(\mathrm{g} / \mathrm{d})$ & $1.56^{\mathrm{b}}$ & $1.48^{\mathrm{b}}$ & $1.54^{\mathrm{b}}$ & $1.97^{\mathrm{a}}$ & 0.06 & $<0.001$ \\
\hline ATTD (\%) & $56 \cdot 2$ & 54.8 & 57.4 & $56 \cdot 9$ & 1.24 & 0.88 \\
\hline Urinary excreted $(\mathrm{g} / \mathrm{d})$ & $0.26^{a, b}$ & $0.09^{c}$ & $0 \cdot 17^{b, c}$ & $0.33^{a}$ & 0.03 & $<0.001$ \\
\hline Retained $(\mathrm{g} / \mathrm{d})$ & $1 \cdot 26^{\mathrm{b}}$ & $1 \cdot 38^{b}$ & $1 \cdot 37^{\mathrm{b}}$ & $1 \cdot 64^{a}$ & 0.04 & $<0.001$ \\
\hline AR $(\%)$ & $45 \cdot 4$ & $51 \cdot 2$ & $51 \cdot 1$ & $47 \cdot 3$ & $1 \cdot 13$ & 0.060 \\
\hline Urinary elimination (\%)† & $17 \cdot 4^{\mathrm{a}}$ & $6 \cdot 4^{\mathrm{b}}$ & $11 \cdot 1^{b}$ & $16 \cdot 5^{a}$ & $1 \cdot 18$ & $<0.001$ \\
\hline \multicolumn{7}{|l|}{$\mathrm{Na}$} \\
\hline Intake $(g / d)$ & $0.61^{a}$ & $0.52^{\mathrm{b}}$ & $0.48^{c}$ & $0.60^{a}$ & 0.01 & $<0.001$ \\
\hline Excreted in faeces $(\mathrm{g} / \mathrm{d})$ & $0.08^{a}$ & $0.09^{a}$ & $0.05^{\mathrm{b}}$ & $0.05^{b}$ & 0.01 & 0.045 \\
\hline Absorbed $(\mathrm{g} / \mathrm{d})$ & $0.54^{\mathrm{a}}$ & $0.43^{b}$ & $0.44^{\mathrm{b}}$ & $0.56^{a}$ & 0.01 & $<0.001$ \\
\hline ATTD $(\%)$ & $87 \cdot 5^{a, b}$ & $82 \cdot 1^{b}$ & $90 \cdot 2^{a, b}$ & $92 \cdot 1^{\mathrm{a}}$ & 1.32 & 0.029 \\
\hline Urinary excreted $(\mathrm{g} / \mathrm{d})$ & 0.11 & 0.09 & 0.13 & 0.18 & 0.02 & 0.15 \\
\hline Retained $(\mathrm{g} / \mathrm{d})$ & 0.43 & 0.34 & 0.30 & 0.37 & 0.02 & 0.13 \\
\hline AR $(\%)$ & 69.9 & $64 \cdot 8$ & 62.9 & $61 \cdot 8$ & 3.09 & 0.84 \\
\hline Urinary elimination (\%)† & $20 \cdot 3$ & 20.9 & $31 \cdot 0$ & $33 \cdot 3$ & 3.23 & 0.39 \\
\hline \multicolumn{7}{|l|}{ K } \\
\hline Intake $(g / d)$ & $2 \cdot 90^{\mathrm{C}}$ & $3.06^{\mathrm{b}}$ & $3 \cdot 31^{\mathrm{a}}$ & $3 \cdot 29^{a}$ & 0.04 & $<0.001$ \\
\hline Excreted in faeces $(\mathrm{g} / \mathrm{d})$ & $0.82^{c}$ & $0.92^{b, c}$ & $1 \cdot 18^{a}$ & $1 \cdot 08^{a, b}$ & 0.04 & 0.001 \\
\hline Absorbed $(\mathrm{g} / \mathrm{d})$ & 2.08 & $2 \cdot 14$ & $2 \cdot 13$ & $2 \cdot 22$ & 0.03 & 0.47 \\
\hline ATTD (\%) & $71 \cdot 5^{\mathrm{a}}$ & $70 \cdot 0^{a, b}$ & $64 \cdot 4^{\mathrm{b}}$ & $67 \cdot 3^{\mathrm{a}, \mathrm{b}}$ & 0.96 & 0.042 \\
\hline Urinary excreted $(\mathrm{g} / \mathrm{d})$ & $1.68^{a, b}$ & $1.43^{\mathrm{b}}$ & $1.79^{a}$ & $1.83^{\mathrm{a}}$ & 0.05 & 0.019 \\
\hline Retained $(\mathrm{g} / \mathrm{d})$ & $0.39^{a, b}$ & $0.71^{a}$ & $0.34^{b}$ & $0.38^{b}$ & 0.05 & 0.025 \\
\hline$A R(\%)$ & $13 \cdot 6^{a, b}$ & $23 \cdot 3^{a}$ & $10 \cdot 3^{b}$ & $11 \cdot 6^{\mathrm{b}}$ & 1.64 & 0.011 \\
\hline Urinary elimination† $(\%) \dagger$ & $80 \cdot 9^{a, b}$ & $67 \cdot 1^{b}$ & $84 \cdot 1^{\mathrm{a}}$ & $82 \cdot 7^{a}$ & $2 \cdot 28$ & 0.018 \\
\hline \multicolumn{7}{|l|}{ S } \\
\hline Intake $(\mathrm{g} / \mathrm{d})$ & $0.80^{\mathrm{b}}$ & $0.98^{\mathrm{a}}$ & $0.98^{a}$ & $0.99^{a}$ & 0.02 & $<0.001$ \\
\hline Excreted in faeces $(\mathrm{g} / \mathrm{d})$ & 0.18 & 0.20 & 0.22 & 0.22 & 0.01 & 0.059 \\
\hline Absorbed $(\mathrm{g} / \mathrm{d})$ & $0.62^{b}$ & $0.78^{a}$ & $0.77^{a}$ & $0.76^{a}$ & 0.01 & $<0.001$ \\
\hline ATTD $(\%)$ & $76 \cdot 9$ & $79 \cdot 8$ & $78 \cdot 1$ & $77 \cdot 6$ & 0.51 & 0.25 \\
\hline Urinary excreted $(\mathrm{g} / \mathrm{d})$ & $0.25^{\mathrm{b}}$ & $0.33^{a}$ & $0.38^{a}$ & $0.36^{a}$ & 0.01 & $<0.001$ \\
\hline Retained $(\mathrm{g} / \mathrm{d})$ & 0.36 & 0.45 & 0.39 & 0.41 & 0.01 & 0.087 \\
\hline AR $(\%)$ & $45 \cdot 5$ & $45 \cdot 7$ & $38 \cdot 8$ & $41 \cdot 3$ & $1 \cdot 17$ & 0.19 \\
\hline Urinary elimination (\%)† & $40 \cdot 9$ & $42 \cdot 8$ & $49 \cdot 1$ & $46 \cdot 9$ & 1.31 & 0.12 \\
\hline \multicolumn{7}{|l|}{$\mathrm{Cl}$} \\
\hline Intake $(\mathrm{g} / \mathrm{d})$ & $2.09^{c}$ & $2 \cdot 06^{c}$ & $4 \cdot 72^{\mathrm{b}}$ & $5 \cdot 03^{a}$ & 0.30 & $<0.001$ \\
\hline Excreted in faeces $(\mathrm{g} / \mathrm{d})$ & $0.14^{c}$ & $0 \cdot 18^{b, c}$ & $0.27^{\mathrm{a}}$ & $0 \cdot 26^{a, b}$ & 0.02 & 0.002 \\
\hline Absorbed $(g / d)$ & $1.95^{\mathrm{c}}$ & $1.88^{\mathrm{C}}$ & $4.45^{\mathrm{b}}$ & $4 \cdot 77^{\mathrm{a}}$ & 0.29 & $<0.001$ \\
\hline ATTD $(\%)$ & $93 \cdot 4^{a, b}$ & $91.4^{\mathrm{b}}$ & $94 \cdot 3^{\mathrm{a}}$ & $94 \cdot 8^{\mathrm{a}}$ & 0.40 & 0.004 \\
\hline Urinary excreted $(\mathrm{g} / \mathrm{d})$ & $1.48^{\mathrm{b}}$ & $1 \cdot 33^{\mathrm{b}}$ & $3 \cdot 82^{\mathrm{a}}$ & $3.78^{a}$ & 0.27 & $<0.001$ \\
\hline Retained $(\mathrm{g} / \mathrm{d})$ & $0.48^{\mathrm{b}}$ & $0.55^{\mathrm{b}}$ & $0.63^{a}$ & $0.98^{\mathrm{a}}$ & 0.06 & 0.003 \\
\hline AR $(\%)$ & $22 \cdot 9^{\mathrm{a}, \mathrm{b}}$ & $26 \cdot 9^{\mathrm{a}}$ & $13 \cdot 1^{\mathrm{b}}$ & $19 \cdot 6^{a, b}$ & 1.68 & 0.014 \\
\hline Urinary elimination (\%)† & $75 \cdot 5^{a, b}$ & $70 \cdot 6^{b}$ & $86 \cdot 1^{\mathrm{a}}$ & $79 \cdot 4^{a, b}$ & 1.83 & 0.009 \\
\hline
\end{tabular}

C, control low-fibre diet; D, diet enriched in local feedstuffs with a normal dietary electrolyte balance; D-A, diet enriched in local feedstuffs with a low dietary electrolyte balance; D-CA, D-A diet supplemented with Ca; ATTD, apparent total tract digestibility; AR, apparent retention.

a,b,c,d Mean values within a row with unlike superscript letters were significantly different $(P<0 \cdot 05)$.

${ }^{*} n 6$.

†Percentage of the amount absorbed, as described in the Materials and methods section.

observed with the low $\mathrm{AEB}$ is related to higher energy costs for the maintenance of acid-base homeostasis. According to Patience \& Wolynetz ${ }^{(32)}$, growth and feed intake appeared to be maximal for a dEB of 0 to $341 \mathrm{mEq} / \mathrm{kg}$, but were decreased at $-85 \mathrm{mEq} / \mathrm{kg}$. From the results of Dersjant-Li et al. ${ }^{(33)}$, a restricted feeding level dEB ranging from -135 to $145 \mathrm{mEq} / \mathrm{kg}$ has little effect on the energy metabolism of young pigs, suggesting that the poor performance observed would be mainly related to a reduced feed intake. Changes at the systemic and urinary levels confirm that regulation 
Table 5. Femur characteristics of piglets fed dietary treatments* (Mean values and pooled standard errors)

\begin{tabular}{|c|c|c|c|c|c|c|}
\hline & C & D & D-A & D-CA & SEM & $P$ \\
\hline Weight (g DM) & $37 \cdot 6$ & $40 \cdot 2$ & $39 \cdot 8$ & $41 \cdot 1$ & 0.71 & 0.094 \\
\hline Ash (g) & $15 \cdot 7$ & $16 \cdot 8$ & $16 \cdot 3$ & $16 \cdot 9$ & 0.21 & 0.081 \\
\hline Ash (\% DM) & $41 \cdot 6$ & $42 \cdot 1$ & 40.9 & 40.5 & 0.81 & 0.47 \\
\hline \multicolumn{7}{|l|}{ Morphometry } \\
\hline Length (cm) & $12 \cdot 14$ & $12 \cdot 36$ & $12 \cdot 19$ & $12 \cdot 34$ & 0.07 & 0.66 \\
\hline $\begin{array}{l}\text { Diaphysis } \\
\text { width }(\mathrm{cm})\end{array}$ & $1.48^{b}$ & $1.59^{a, b}$ & $1 \cdot 56^{a, b}$ & $1.67^{\mathrm{a}}$ & 0.02 & 0.017 \\
\hline $\begin{array}{l}\text { Medullar cavity } \\
\text { width }(\mathrm{cm})\end{array}$ & $1.07^{\mathrm{b}}$ & $1 \cdot 13^{a, b}$ & $1 \cdot 17^{\mathrm{a}}$ & $1 \cdot 20^{a}$ & 0.02 & 0.014 \\
\hline $\begin{array}{l}\text { Cortical } \\
\text { thickness }(\mathrm{cm})\end{array}$ & 0.42 & 0.46 & 0.39 & 0.47 & 0.02 & 0.22 \\
\hline $\begin{array}{l}\text { Cortical area } \\
\left(\mathrm{cm}^{2}\right)\end{array}$ & $3.33^{b}$ & $4 \cdot 09^{a, b}$ & $3.47^{b}$ & $4.44^{a}$ & 0.15 & 0.020 \\
\hline \multicolumn{7}{|c|}{ Bone mineral density $\left(\mathrm{g} / \mathrm{cm}^{3}\right)$} \\
\hline Entire bone & 1.266 & $1 \cdot 270$ & 1.268 & $1 \cdot 270$ & 0.001 & 0.64 \\
\hline Trabecular & $1 \cdot 212$ & $1 \cdot 214$ & $1 \cdot 212$ & $1 \cdot 213$ & 0.001 & 0.81 \\
\hline Cortical & 1.677 & 1.670 & 1.680 & 1.666 & 0.003 & 0.29 \\
\hline \multicolumn{7}{|c|}{ Mineral content (g/femur) } \\
\hline $\mathrm{P}$ & $2 \cdot 885^{\mathrm{b}}$ & $3.224^{a}$ & $3 \cdot 135^{\mathrm{a}, \mathrm{b}}$ & $3.213^{\mathrm{a}}$ & 0.050 & 0.045 \\
\hline $\mathrm{Ca}$ & $5 \cdot 314$ & $5 \cdot 901$ & $5 \cdot 732$ & $5 \cdot 842$ & 0.090 & 0.067 \\
\hline $\mathrm{Na}$ & 0.226 & 0.243 & 0.243 & 0.239 & 0.004 & 0.18 \\
\hline $\mathrm{K}$ & 0.115 & 0.116 & 0.117 & 0.111 & 0.003 & 0.89 \\
\hline $\mathrm{S}$ & 0.083 & 0.087 & 0.097 & 0.087 & 0.004 & 0.30 \\
\hline $\mathrm{Cl}$ & 0.119 & 0.129 & 0.126 & 0.126 & 0.002 & 0.27 \\
\hline Ca:P ratio & $1 \cdot 845$ & 1.832 & 1.828 & 1.818 & 0.009 & $0 \cdot 16$ \\
\hline
\end{tabular}

C, control low-fibre diet; D, diet enriched in local feedstuffs with a normal dietary electrolyte balance; D-A, diet enriched in local feedstuffs with a low dietary electrolyte balance; D-CA, D-A diet supplemented with $\mathrm{Ca}$.

$\mathrm{a}, \mathrm{b}$ Mean values within a row with unlike superscript letters were significantly different $(P<0 \cdot 05)$.

${ }^{*} n 6$.

processes occurred. The kidney contributes to the excretion of the acid load, allowing the plasma $\mathrm{pH}$ to be maintained in a physiological range. Part of the overload of dietary $\mathrm{Cl}$ was excreted in the urine with a counterbalance of cations, mainly in the form of $\mathrm{NH}_{4}^{+}$and, to a lesser extent, $\mathrm{K}^{+}, \mathrm{Ca}^{2+}$ and $\mathrm{Na}^{+}$. In response to metabolic acidosis, higher urinary ammonia excretion is the primary component of the increase in net acid excretion ${ }^{(34)}$. A six-fold increase in urine ammonia flux was also observed when reducing the dEB from 163 to $-20 \mathrm{mEq} / \mathrm{kg}^{(4)}$. Indeed, renal gluconeogenesis and ammoniagenesis are stimulated to regenerate $\mathrm{HCO}_{3}^{-}$and provide $\mathrm{NH}_{4}^{+}$ in equivalent amounts ${ }^{(35)}$. Then $\mathrm{HCO}_{3}^{-}$is returned to the systemic circulation, whereas ammonia $\left(\mathrm{NH}_{4}^{+}\right.$and $\left.\mathrm{NH}_{3}\right)$ is excreted in the urine to regulate net acid excretion ${ }^{(34)}$. Glutamine is the primary metabolic source for ammoniagenesis and its renal uptake increases substantially during metabolic acidosis. The acidification also induced a higher loss of $\mathrm{K}$ from the body. Potassium is the main intracellular cation, primarily stored in muscle, and its concentration is finely maintained by $\mathrm{Na}-\mathrm{K}$ pumps. This tight regulation is critical for normal cell function, and low-grade metabolic acidosis is known to induce a net loss of cellular $\mathrm{K}^{(36)}$. The difficulty in maintaining the intracellular pool of $\mathrm{K}$ could partly explain the observed loss of performance.

The acidification also resulted in a marked excretion of phosphate, which is the major $\mathrm{H}^{+}$buffer system in urine. Its excretion is increased during acidosis as a result of a decrease of the preferentially transported form $\left(\mathrm{HPO}_{4}^{2-}\right)$, together with a direct effect of the luminal $\mathrm{pH}$ on the apical phosphate carriers ( NaPiIIa and IIc) in the proximal tubule ${ }^{(37)}$. The additional urinary $\mathrm{P}$ output $(3 \mathrm{~g}$ estimated on $30 \mathrm{~d}$ ) represented the $\mathrm{P}$ content of the femur of a 2-month-old piglet. Although not significant, the acidification tended to depress some femur characteristics, suggesting a change in bone resorption or a decrease in bone mineral deposition. In agreement with Budde \& Crenshaw ${ }^{(20)}$, a higher $\mathrm{Cl}$ retention was observed, which may suggest the storage of $\mathrm{Cl}$ in bone. This may contribute to the buffering of the acid load through the exchange of $\mathrm{Cl}$ for other anions such as phosphate, which in turn is released. However, the level of $\mathrm{Cl}$ in the femur did not change significantly, contradicting the hypothesis that bone was a storage compartment for excess $\mathrm{Cl}$. This cannot be confirmed as only the femur was analysed, which is not representative of the overall skeleton. The femur is made up of cortical bone, and it is less vascularised compared with trabecular/spongy bone ${ }^{(38)}$. Consequently, the dynamics of exchanges with the blood could be different between those two types. The role of the skeleton could be less important than previously stated, especially since competition between the need to eliminate acid loads and the need to form bone probably occurs due to the high growth rate of piglets. According to Budde \& Crenshaw ${ }^{(20)}$, feeding piglets for 3 weeks post-weaning with a lower $\mathrm{dEB}(-35 v$. 212) did not impair bone mineral and ash content or bone breaking strength. This discrepancy between these results and those of the present study could be explained by the higher level of $\mathrm{Ca}$ used by the authors $(9 \cdot 6$ v. $6 \cdot 5 \mathrm{~g} / \mathrm{kg})$.

Currently, dietary $\mathrm{Ca}$ tends to be reduced as it can antagonise $\mathrm{P}$ absorption $^{(39)}$ and deteriorate growth performance. As quantified by Létourneau-Montminy et al. ${ }^{(13)}$, increasing Ca from 5 to $8 \mathrm{~g} / \mathrm{kg}$ induces a reduction of $0 \cdot 10 \mathrm{~g}$ digestible $\mathrm{P} / \mathrm{kg}$ regardless of the dietary $\mathrm{P}$ concentration. In the present study, increasing the Ca level from 6.4 to $8.2 \mathrm{~g} / \mathrm{kg}$ was not detrimental to $\mathrm{P}$ digestibility. In addition, $\mathrm{Ca}$ supplementation tended to reduce the negative effect of $\mathrm{Cl}$ overload, but without fully counteracting its acidifying effect at systemic and urinary levels. Ca partly contributes to the neutralisation of $\mathrm{Cl}$ anions in the urine, with a consecutive sparing effect of phosphate, which is more easily reabsorbed. Additionally, the higher Ca supply may favour the deposition of $\mathrm{P}$ in the skeleton, thereby improving bone characteristics, particularly in the cortical area. As the cortical area represents the strongest part of the bone, higher mineral quality and strength can be expected, which could be determinant later during the growing period. It should be noted that bone mineral density was not affected. This is in agreement with Viguet-Carrin et al. ${ }^{(40)}$, who observed a significant increase in bone strength and femur length which was not accompanied by an increase in bone mineral density or bone markers in growing rats fed diets with high $\mathrm{Ca}$ levels. This result highlights the importance of $\mathrm{Ca}$ in the regulation of the acid-base balance beyond the components of the $\mathrm{dEB}$.

\section{Conclusion}

The results of the present study suggest that the increasing use of various local feedstuffs in feed formula requires adapting 
the $\mathrm{dEB}$ when formulating diets to avoid any over-excretion of $\mathrm{P}$ and ammonia. In parallel, a higher $\mathrm{Ca}$ level must be considered to counteract the negative effects of low-grade metabolic acidosis on $\mathrm{P}$ excretion and prevent bone alteration.

\section{Acknowledgements}

The authors are grateful to E. Labussière for his scientific expertise and advice, M. Couty and S. Urvoix for their help during blood and slaughtered sampling and laboratory analyses, S. Daré for her technical support concerning blood gas analyses, Y. Jaguelin-Peyraud and C. Perrier for their help and laboratory expertise, F. Le Gouevec, J. George, A. Chauvin, M. Genissel, G. Guillemois, H. Demay, R. Janvier, M. Alix and V. Piedvache for their help and animal care throughout the entire experiment.

The present study was funded by MiXscience, Terres UNIVIA and Terres INOVIA (FLUMINE, 32000 580).

M. B. contributed to all aspects of the research including definition of the design, data collection, statistical analyses, interpretation of results and manuscript drafting. M. J. D., D. G. C. P. and A. Q. contributed to the definition of the design, interpretation of the data and manuscript preparation and F. L. and N. M. to data collection and manuscript preparation. A. N. contributed to the definition of the design, data collection, interpretation of data and manuscript preparation.

There were no conflicts of interest.

\section{References}

1. Remer $T$ (2001) Influence of nutrition on acid base balance - metabolic aspects. Eur J Nutr 40, 214-220.

2. Nowik M, Picard N, Stange G, et al. (2008) Renal phosphaturia during metabolic acidosis revisited: molecular mechanisms for decreased renal phosphate reabsorption. Eur J Physiol 457, 539-549.

3. Carnauba RA, Baptistella AB, Paschoal V, et al. (2017) Diet-induced low-grade metabolic acidosis and clinical outcomes: a review. Nutrients $\mathbf{9}, 538-554$.

4. Patience JF \& RK Chaplin (1997) The relationship among dietary undetermined anion, acid-base balance, and nutrient metabolism in swine. J Anim Sci 75, 2445-2452.

5. Jajo R, Song L, Rasmussen H, et al. (2006) Dietary acid-base balance, bone resorption, and calcium excretion. J Am Coll Nutr 25, 224-230.

6. Bushinski DA \& Frick KK (2000) The effect of acid on bone. Curr Opin Nephrol Hypertens 9, 359-379.

7. Esche J, Johner S, Shi L, et al. (2016) Urinary citrate, an index of acid-base status, predicts bone strength in youths and fracture risk in adult females. J Clin Endocrinol Metab 101, 4914-4921.

8. Patience JF \& Wolynetz MS (1990) Influence of dietary undetermined anion on acid-base status and performance in pigs. $J$ Nut 120, 579-587.

9. Lei XG, Chung JY, Park JH, et al. (2017) Evaluation of different dietary electrolyte balance in weanling pigs diets. Anim Feed $S_{c i}$ Tech 226, 98-102.

10. Apper-Bossard E, Peyraud JL \& Dourmad JY (2009) Effet du bilan électrolytique de la ration sur l'équilibre acido-basique et les performances zootechniques des animaux domestiques à fort niveau de production (Effect of electrolyte balance of the ration on acidbase balance and zootechnical performances of domestic animals at high production level). Inra Prod Anim 22, 117-130.
11. INRA-AFZ (2004) Tables de composition et de valeur nutritive des matières premières destinées aux animaux d'élevage: Porcs, Volailles, Bovins, Ovins, Caprins, Lapins, Chevaux, Poissons (Composition and Nutritional Value Tables of Raw Materials Intended for Farm Animals: Pigs, Poultry, Cattle, Sheep, Goats, Rabbits, Horses, Fish), 2nd ed. [D Sauvant, JM Pérez and G Tran, editors]. Paris: INRA Editions.

12. Dersjant-Li Y, Verstegen MWA, Schulze H, et al. (2001) Performance, digesta characteristics, nutrient flux, plasma composition and organ weight in pigs as affected by dietary cation anion difference and non-starch polysaccharides. J Anim Sci 79, 1840-1848.

13. Létourneau-Montminy M, Jondreville C, Sauvant D, et al. (2012) Meta-analysis of phosphorus utilization by growing pigs: effect of dietary phosphorus, calcium and exogenous phytase. Animal 6, 1590-1600.

14. Eklou-Kalonji E, Zerath E, Colin C, et al. (1994) Calcium-regulating hormones, bone mineral content, breaking load and trabecular remodeling are altered in growing pigs fed calcium-deficient diets. J Nutr 129, 188-193.

15. Jondreville C \& Dourmad JY (2005) Phosphorus in pig nutrition. INRA Prod Anim 18, 183-192.

16. Prosky L, Asp NG, Schweizer TF, et al. (1988) Determination of insoluble, soluble, and total dietary fibre in foods and food products: interlaboratory study. J Assoc Off Anal Chem Int 71, 1017-1023.

17. Militist G, Donkó T, Dalle Zotte A, et al. (2013) Application of computed tomography to assess the effect of egg yolk ratio on body composition in chickens of different genotypes and gender at hatch and during the rearing period. Br Poult Sci 54, 611-619.

18. Sherlock ML, Demmers TGM, Goodship AE, et al. (2010) The relationship between physical activity and leg health in the broiler chicken. Br Poult Sci 51, 22-30.

19. Bournazel M, Lessire M, Duclos MJ, et al. (2018) Effects of rapeseed meal fiber content on phosphorus and calcium digestibility in pigs fed diets without or with microbial phytase. Animal 12, 34-42.

20. Budde RA \& Crenshaw TD (2003) Chronic metabolic acid load induced by changes in dietary electrolyte balance increased chloride retention but not compromise bone in growing swine. J Anim Sci 81, 187-208.

21. Kerr BJ \& Surshon GC (2013) Strategies to improve fiber utilization on swine. J Anim Sci Biotechnol 4, 11.

22. Demigné C, Sabboh H, Puel C, et al. (2004) Organic anions and potassium salts in nutrition and metabolism. Nutr Res Rev 17, 249-258.

23. Nielsen TS, Laerke HN, Theil PK, et al. (2014) Diets high in resistant starch and arabinoxylan modulate digestion processes and SCFA pool size in the large intestine and faecal microbial composition in pigs. Br J Nutr 112, 1837-1849.

24. Demigné C, Rémésy C \& Morand C (1999) Short chain fatty acids. In Colonic Microbiota, Nutrition and Health, pp. 55-70 [GR Gibson and MB Roberfroid, editors]. Dordrecht, The Netherlands: Kluwer.

25. Crenshaw TD (2000) Calcium, phosphorus, vitamin D, and vitamin $\mathrm{K}$ in swine nutrition. In Swine Nutrition, 2nd ed. [AJ Lewis and LL Southern, editors]. Boca Raton, FL: CRC Press.

26. Létourneau-Montminy MP, Narcy A, Magnin M, et al. (2010) Effect of reduced dietary calcium concentration and phytase supplementation on calcium and phosphorus utilization in weanling pigs with modified mineral status. J Anim Sci 88, 1706-1717.

27. Levrat-Verny MA, Coudray C, Bellanger J, et al. (1999) Whole wheat flour ensures higher mineral absorption and bioavailability than white wheat flour in rats. Br J Nutr 82, 17-21.

28. Scholz-Ahrens KE \& Schrezenmeir J (2002) Inulin, oligo-fructose and mineral metabolism - experimental data and mechanism. Br J Nutr 87, S179-S188.

29. Scholz-Ahrens KE \& Schrezenmeir J (2007) Inulin and oligofructose and mineral metabolism: the evidence from animal trials. J Nutr 137, 2513S-2523S.

30. Roberfroid, M, Gibson G, Hoyles L, et al. (2010). Prebiotic effects: metabolic and health benefits. Br J Nutr 104, S1-S63. 
31. Birkett AM \& Francis CC (2010) Short-chain fructo-oligosaccharide, a low molecular weight fructan. In Prebiotics and Probiotics, pp. 13-38 [SS Cho and ET Finocchiaro, editors]. Boca Raton, FL: CRC Press.

32. Patience JF \& Wolynetz MS (1990) Influence of dietary undetermined anion on acid-base status and performance in pigs. $J$ Nutr 120, 579-587.

33. Dersjant-Li Y, Schrama JW, Heetkamp MJW, et al. (2002) Effect of dietary electrolyte balance on metabolic rate and energy balance in pigs. Anim Sci 74, 299-305.

34. Weiner ID \& Verlander JW (2013) Renal ammonia metabolism and transport. Compr Physiol 3, 201-220.

35. Curthoys NP \& Moe OW (2014) Proximal tubule function and response to acidosis. Clin J Am Soc Nephrol 9, 1627-1638.
36. Palmer BF (2015) Regulation of potassium homeostasis. Clin J Am Soc Nephrol 10, 1050-1060.

37. Ambühl PM, Zajicek HK, Wang H, et al. (1998) Regulation of renal phosphate transport by acute and chronic metabolic acidosis in the rat. Kidney Int 53, 1288-1298.

38. Kline G, Orton D \& Sadrzadeh H (2017) Bone metabolism. In Endocrine Biomarkers [H Sadrzadeh and G Kline, editors]. Kidlington, Oxfordshire: Elsevier Inc.

39. Heaney RP \& Nordin BEC (2002) Calcium effects on phosphorus absorption: implications for the prevention and co-therapy of osteoporosis. J Am Coll Nutr 21, 239-244.

40. Viguet-Carrin S, Hoppler M, Membrez SF, et al. (2014) Peak bone strength is influenced by calcium intake in growing rats. Bone $\mathbf{6 8 , 8 5 - 9 1 .}$ 